\title{
Time for Solidarity: Liturgical Time in Disaster Capitalism
}

\author{
Mark Roosien
}

check for updates

Citation: Roosien, Mark. 2021. Time for Solidarity: Liturgical Time in Disaster Capitalism. Religions 12: 332 https://doi.org/10.3390/rel12050332

Academic Editor: Edward Foley

Received: 24 April 2021

Accepted: 5 May 2021

Published: 11 May 2021

Publisher's Note: MDPI stays neutral with regard to jurisdictional claims in published maps and institutional affiliations.

Copyright: (C) 2021 by the author. Licensee MDPI, Basel, Switzerland. This article is an open access article distributed under the terms and conditions of the Creative Commons Attribution (CC BY) license (https:/ / creativecommons.org/licenses/by/ $4.0 /)$.
Institute of Sacred Music, Yale University, New Haven, CT 06511, USA; mark.roosien@yale.edu

\begin{abstract}
This article identifies the upheaval of many people's experience of time during the COVID19 pandemic as part of a larger phenomenon of the $24 / 7$ temporality that can be seen to contribute to the environmental destruction and social fragmentation typical of disaster capitalism. It then proposes liturgical temporality as an alternative to $24 / 7$ temporality, framing it as a fitting context for the cultivation of solidarity between human beings and between human beings and the natural world. It argues that modern Jewish and Christian theologies of Sabbath-keeping as a mode of liturgical and ethical praxis have articulated a liberative vision for shared liturgical temporality but have not paid sufficient attention to concrete, collective modes of liturgical time keeping that could contend with the all-encompassing reality of $24 / 7$ life. It concludes by discussing three ways that a more robust spirituality and praxis of liturgical time could support the cultivation of solidarity: a sense of the present that is mindful of the past and future, the invitation of practitioners into a shared story, and meaningful repetition toward the appropriation of a vision of redemption and liberation for human and non-human life.
\end{abstract}

Keywords: liturgy; worship; pandemic; time; capitalism; ritual; liberation theology; Sabbath; COVID-19; ethics

\section{Introduction}

The COVID-19 pandemic altered the everyday experience of time for many people living in modernized, Western societies. As in-person social gatherings were largely replaced by virtual ones, the boundaries between home and work, rest and waking, and personal time and professional time significantly eroded. The pandemic seemed to create a protracted liminal time: a period of uncertainty after previous structures of life had been upended, but new, stable structures had yet to form (see Bell 2021). However, pandemic time was not so much an interruption of a previous, "normal" time as it was an acceleration of what media theorist Jonathan Crary has called the 24/7 time of late capitalism, a temporal regime in which market forces seek to extract maximum profit value from each moment, whether one is on or off the clock (Crary 2013). The rise of 24/7 time in the last two decades has been aided by the growing ubiquity of smart technologies that allow for productivity and consumption to proceed without pause for shared breaks or vacations. Accelerated during the COVID-19 pandemic, 24/7 time is a new temporality for the twenty-first century: a horizon of meaning by which and through which individuals experience the temporal dimension of life.

Critics argue that 24/7 temporality-time as digitalized, monetized, and relentlessly ongoing - is catastrophically unsuited for human and non-human flourishing. It enables environmental destruction, economic inequality, and social fragmentation (Chan 2020, p. 2). As media theorist Nadine Chan has recently written, the individualized digital lifeworlds of 24/7 temporality take us "further away from contemporaneous and inhabited ecological time." (Chan 2020, p. 2). Those concerned with the short- and long-term perils of capitalist temporality have long sought strategies to transcend or resist this temporal regime. ${ }^{1}$ Yet 24/7 time presents a new challenge since individual efforts to imagine new temporalities become easily trapped in the very fragmented, asynchronous lifeworlds that $24 / 7$ time 
creates. How might people, in Chan's words, "learn to be contemporaneous together" under the 24/7 regime? (Chan 2020, p. 6).

In this paper, I propose that liturgical temporality could provide an alternative temporal context for religious communities to cultivate solidarity in all its dimensions: economic, social, ecological, and spiritual. ${ }^{2}$ During the COVID-19 pandemic, religious communities struggled to maintain connection with their liturgical rhythms. Yet this struggle, too, was not new to the pandemic; it merely revealed with stark clarity the fundamental discordance between liturgical temporality and late capitalist temporality. In recent decades, Christian and Jewish theologians have noted this discordance and explored Sabbath-keeping as means of resisting inhumane time cycles. Modern theologians of Sabbath-keeping provide a useful framework for imagining shared liturgical time as a context for liberative practices of rest, prayer, gathering, protest, and critique. However, most do not offer concrete strategies for living in liturgical temporality in ways that could challenge the all-encompassing reality of 24/7 life. A more robust articulation of liturgical temporality that builds upon Sabbath practices and spiritualities but more fully embraces daily, weekly, seasonal, and annual aspects of time could provide a stronger framework for communities to practice what Pope Francis calls "habits of solidarity." Such habits can inspire people to adopt a "new mindset which thinks in terms of community and the priority of the life of all over the appropriation of goods by a few." (Francis 2013, para. 188). Additionally, "when they are put into practice, [they] open the way to other structural transformations and make them possible." (Francis 2013, para. 189). Drawing from philosopher Christina Gschwandtner's recent phenomenological study of Orthodox Christian liturgical temporality, I narrate specific ways that it could serve as a shared spiritual and practical horizon in which to cultivate solidarity between people of various groups and between human beings and the earth, and offer an alternative to the present temporal order of consumption, waste, and the reckless pursuit of profit.

\section{24/7: The Temporality of Disaster Capitalism}

During the pandemic, it was often difficult to determine what day it was, an experience social media users wryly dubbed "Blursday." 3 For many, the experience of time was filtered through digital media that operated on 24/7 timeframes: virtual classrooms, social media, Zoom and other video conferencing software, video streaming and retail sites, etc. ${ }^{4}$ Lockdowns forced many to dwell almost continuously within digital spaces, which in turn allowed the pace of consumption to proceed uninhibited by the restrictions of shared periods of rest or vacation. As a result, large tech and retail corporations, such as Amazon and Google, posted record-breaking profit numbers in 2020. ${ }^{5}$ Measures taken out of necessity during the pandemic, such as working from home, will likely remain in place after the pandemic is over and further perpetuate the erasure of boundaries between work and home, and on-the-clock and off-the-clock time. ${ }^{6}$ The success of corporate conglomerates and the upward transfer of wealth during the pandemic vindicates the "disaster capitalism" thesis that large corporations and wealthy individuals often benefit from social and environmental upheaval. ${ }^{7}$ In this way, the COVID-19 pandemic was a moment of truth that accelerated the rise of $24 / 7$ temporality already underway. It also revealed the extent to which those at the top of social and economic hierarchies benefit from this temporal regime to the detriment of other human beings and the earth. Disaster capitalism and disaster temporality come as a pair, leaving environmental destruction and social fragmentation in their wake. ${ }^{8}$

The record corporate profits generated under pandemic conditions represent only the most recent example of how market forces organize time in ways that maximize monetary yield. ${ }^{9}$ More than half century ago, historian Jacques Le Goff made the influential argument that, beginning in the high middle ages, "merchant's time", measured by fixed calculations of minutes and hours, gradually displaced Western Europe's looser, shared rhythms of "church's time." The latter was determined by the liturgical offices and seasons of the church, measured by sundials and crude water clocks, and announced by bells. Merchant's 
time inaugurated the extractive attitude toward time neatly encapsulated in the phrase "time is money" and was (at first) vehemently attacked by the church. ${ }^{10}$ Crary argues that twenty-first-century $24 / 7$ temporality not only perpetuates this extractive attitude toward time but also constitutes a genuinely new horizon for temporal experience. Crary writes that 24/7 temporality, "can be characterized as a generalized inscription of human life into duration without breaks, defined by a principle of continuous functioning. It is a time that no longer passes, beyond clock time." (Crary 2013, p. 8). In 24/7 temporality, all days become Blursday. ${ }^{11}$

24/7 temporality is not simply a continuous capture of one's attention but is also a dense layering of time in which multiple things (ads, clicks, Tweets) embedded in a single visual/temporal space can be attended to in a nearly simultaneous instant. Smart technologies have created new rhythms, speeds, and formats through which actions can be easily monetized, even actions as subtle as resting one's gaze momentarily upon an image on the screen of a smartphone (Crary 2013, p. 39). Time is experienced as a constantly reloading "now" that seems ever new. However, despite their differing content, digital experiences are created to be interchangeable and thus monetizable. Global markets rely on the predictable actions of large populations and benefit from the sameness and repetition at work in digital lifeworlds (Crary 2013, p. 56). The paradoxically repetitive newness of digitally-mediated human interaction with the world, Crary argues, encourages practices that are indifferent to past or future horizons-except, perhaps, a short-term future dominated by desire for all-too-finite satisfactions. ${ }^{12}$ One might hold onto the false hope that one more click will open up something genuinely new to counter the monotony in which one is immersed, but it is not meant to be (Crary 2013, p. 88).

The widespread habitation of digital lifeworlds with their own disjunctive temporalities would seem to preclude the formation of a shared temporality capable of contending with 24/7 time. However, Nadine Chan saw a flicker of hope for asynchronous solidarity during the COVID-19 pandemic. She argues that the social lockdowns necessitated by the two-week incubation period of the coronavirus created the possibility of a "collective, explosive, revolutionary time." Such a collective, revolutionary time was witnessed in the summer 2020 Black Lives Matter resurgence in the U.S. and around the world as people gathered together in streets and plazas, often at unpredictable times, to protest racial oppression (Chan 2020, p. 6). Chan writes, "Amid the energies of collective action, digital asynchrony may also be the path towards inhabited futures that are not so [digital]."13 Chan is cautiously optimistic that a reimagination of a shared, collective future could take place amidst the proliferation of digital temporalities, a future in which multiple groups and individuals could act in solidarity to resist to the destructive practices and demands of disaster capitalism.

While digital technology is certain to be part of any future temporal arrangement, it is uncertain that the present fragmented, asynchronous temporality of 24/7 life can allow for a sustainable maintenance of solidarity. Crary holds that digital lifeworlds are ineffective as contexts for collective action since "overlaid onto them are all the practices of individual time management made possible by $24 / 7$ networks and markets." ${ }^{14}$ While digital lifeworlds provide a platform for inspired creativity and expression, their temporal frame remains firmly rooted in timekeeping habits designed to be monetized, exploited, and individualized. Indeed, because of the market's demand for homogeneity and substitutability, Crary contends that $24 / 7$ temporality is incompatible with "any social behaviors that have a rhythmic pattern of action and pause. This would include any social exchange involving sharing, reciprocity or cooperation." (Crary 2013, p. 125). Solidarity is hence likely to be most sustainable when it is rooted in shared temporality, which seems elusive within the $24 / 7$ time of disaster capitalism. ${ }^{15}$

\section{Sabbath as Resistance to 24/7 Temporality: Promise and Pitfalls}

What are the possibilities for forming a shared temporality? Recently, both religious and non-religious people alike have sought out timekeeping practices as seemingly 
mundane as napping and doing nothing (intentionally) through which to transcend or resist 24/7 time. ${ }^{16}$ Since the mid-twentieth century, Jewish and Christian theologians have framed the keeping of the Sabbath as an antidote to the frantic speed of modern life. The accounts of these theologians are worth exploring as a point of departure for religious communities seeking a liberative spirituality in which to "be contemporaneous together" in solidarity. However, they often fall short of meaningfully contending with the all-encompassing nature of 24/7 temporality, both by neglecting to recommend concrete shared practices of timekeeping and overlooking the crucial role of capitalist ideology as the source of the temporality they oppose.

The most important theological consideration of the Sabbath in the twentieth century is arguably the classic 1951 book by American-Polish rabbi and philosopher Abraham Joshua Heschel, The Sabbath: Its Meaning for Modern Man (1951). Heschel frames Sabbath keeping as an important spiritual and social practice for Jews in the twentieth century. He writes, "Is our civilization a way to disaster, as many of us are prone to believe? ... The faith of the Jew is not a way out of this world, but a way of being within and above this world; not to reject but to surpass civilization. The Sabbath is the day on which we learn the art of surpassing civilization." (Heschel 1951, p. 26). In Heschel's view, the Sabbath is a way of keeping time that allows individuals and communities to transcend the anxiety-inducing temporality of modern life while remaining active participants in society and working for its improvement. ${ }^{17}$

Many Christian theologians have drawn from Heschel's social-spiritual account of the Sabbath. In her 1989 book, Keeping the Sabbath Wholly: Ceasing, Resting, Embracing, Feasting, Christian theologian Marva J. Dawn cites the Sabbath practice of rest from work on Sunday or Saturday to inform broader practices of "ceasing, resting, embracing, [and] feasting," as per the subtitle of the book. ${ }^{18}$ Pope John Paul II, in his 1998 apostolic letter Dies Domini, similarly draws from Jewish understandings of the Sabbath to inform the Christian observance of Sunday. Sunday, he argues, should be understood in the context of the biblical Sabbath, which he calls "a determining element in the kind of 'sacred architecture' of time which marks biblical revelation. It recalls that the universe and history belong to God; and without a constant awareness of that truth, man cannot serve in the world as co-worker of the Creator." (John Paul II 1998, section 1:15). For John Paul II, a Sabbathinspired understanding of Sunday, which could include practices such as resting from work, reminds Christians that all time belongs to God and not to the marketplace. Many Christian theologians and spiritual writers have also framed Sabbath-keeping as a means to promote a "slower, simpler style of living," (see Hartman 2011, p. 58) to inspire the patronage of local food producers, and to encourage more intentional care for the natural environment (Hartman 2011, p. 59).

While these writers correctly see liturgical time, specifically Sabbath-keeping, as an important alternative to the modern temporal order, they often give little attention to strategies for collective praxis. ${ }^{19}$ Many eschew the communal practice of resting from work on a fixed day of the week and advocate instead for do-it-yourself practices of individual rest and reflection..$^{20}$ Without a vision of collective action, such individualized practices could easily dissolve into the fragmentary, asynchronous framework of $24 / 7$ temporality. These authors also appear not to recognize capitalism as the substratum that upholds the temporality they seek to transcend and resist, using instead terms such as "consumerism" that carry less critical weight. ${ }^{21}$ When these authors neglect to diagnose capitalist ideology as the source of the present temporal regime, readers who follow them risk falling prey to the strategies of individualization and monetization key to the $24 / 7$ project.

Two recent theologians have framed Sabbath-keeping as a mode of collective response to the 24/7 demands of late capitalism more explicitly than the authors previously mentioned. In his 2014 book, Sabbath as Resistance: Saying No to the Culture of Now, Walter Brueggemann frames a Sabbath spirituality of time as "an alternative to the endless demands of economic reality, more specifically the demands of market ideology." (Brueggemann 2017, p. xii). For Brueggemann, the present socio-economic order is akin to 
Pharaoh's regime in the book of Exodus. Keeping the Sabbath in imitation of the Israelites is how the people of God as a whole are witness to values higher than the insatiable urges of the market. The Sabbath, broadly understood, thus becomes an "occasion for reimagining all social life away from coercion and competition for compassionate solidarity." (Brueggemann 2017, p. 45). Brueggemann stresses that such solidarity is not achieved by sharing the mere idea of Sabbath-keeping; it requires concrete, shared liturgical, ethical, and economic praxis (Brueggemann 2017, p. 18).

Theologian Daniel Castillo has recently expanded upon Brueggemann's theologizing about the Sabbath to stress even more forcefully the importance of shared temporality for building habits of solidarity between various socio-economic groups and between human beings and the earth. Drawing from the tradition of liberation theology, Castillo argues that the regular, repeated practice of Sabbath-keeping (which can be read as gathering for worship on Sundays) should continuously challenge the community "to maintain its prophetic edge in negotiating with the globalization project's ways of organizing creation." (Castillo 2019, p. 208). Sabbath-keeping allows communities to "discern the times" in order to clarify the shape of religious and ethical-political praxis, to gather in community as a witness against the "fragmenting and isolating mechanisms" of late capitalism, and to celebrate in joyful hope of God's victory over the power of sin and death (Castillo 2019, pp. 210-11). Sabbath practices are necessary to achieve the goals of solidarity and liberative discipleship because such a difficult commitment must be constantly renewed, week by week (Castillo 2019, p. 207).

Brueggemann's and Castillo's understandings of the Sabbath improve upon previous articulations by naming capitalism explicitly and by framing liturgical praxis as a providing a temporal horizon for the cultivation of solidarity to defy the fragmentation and destruction of 24/7 temporality. However, like the other theologians of Sabbath mentioned above, they do not offer models for shared, collective praxis or explain why solidarity might take shape within this temporal framework. A spirituality of liturgical time that remains untethered to concrete, collective practices cannot sufficiently address the all-encompassing nature of 24/7 temporality. An articulation of a more robust praxis of liturgical time is needed, one that preserves and extends a liberative spirituality of the Sabbath.

\section{Beyond the Sabbath: Liturgical Temporality as Time for Solidarity}

For the remainder of this essay, I will propose that the Christian tradition possesses a rich liturgical spirituality and praxis of time that could provide a temporality in which to "learn to be contemporaneous together," to invoke Chan once again. With the embrace of a robust vision and praxis of liturgical temporality, communities could link the story of redemption as it unfolds in liturgical time with concrete, communal actions that build solidarity with marginalized persons and groups, and the natural world. ${ }^{22}$ Ritual-liturgical practices, of course, cannot guarantee the outcomes one might desire from them. As Lauren Winner has recently argued, liturgical practices can not only form but also de-form in ways that are specific to the nature of those practices. ${ }^{23}$ One possible de-formative function of keeping steadfastly to a robust liturgical temporality, precisely because it can provide a rich context for group formation, is to encourage exclusivism and triumphalism within the community. ${ }^{24}$ For example, one can observe a tendency within some contemporary Orthodox Christian groups that strictly follow the Julian Calendar or "Old Calendar" to condemn and alienate other Orthodox and otherwise Christian groups that use the newer, Gregorian calendar, accusing them of error and even doctrinal heresy. ${ }^{25}$ Nevertheless, liturgical temporality possesses unique features that can allow for solidarity to take shape within a wide-ranging and multi-layered temporal framework that counteracts certain deformative effects of $24 / 7$ time.

Philosopher Christina Gschwandtner's recent book Welcoming Finitude: Toward a Phenomenology of Orthodox Liturgy gives an account of how liturgical temporality can work in the Orthodox Christian tradition, a tradition with an especially robust and vigorous tradition of liturgical time keeping throughout days, weeks, seasons, and years. ${ }^{26}$ She 
draws from philosophers in the European tradition of phenomenology, especially Martin Heidegger, to explain how liturgical time can become the primary temporal horizon for a community's experience. ${ }^{27}$ Gschwandtner's account demonstrates how liturgical temporality could provide a shared context for the cultivation of habits of solidarity in service of spiritual resistance to the destructive effects of 24/7 temporality. Below, I discuss three specific ways in which liturgical temporality could allow this to take shape.

First, liturgical temporality rejects an extractive attitude toward time. In 24/7 temporality, the individual inhabits a present that is largely indifferent to the past and moves into the future via the satiation of desires generated by ever-reloading stimuli and ever-new consumer products. Aided by the practice of systematic forgetting, extraction proceeds without witness to the destruction it causes. By contrast, the liturgical "now" is structured by remembrance of the past and hope for the future. Gschwandtner contends, "The liturgical present is only given meaningfully it if is precisely given at the same time and within the same moment as memory and anticipation." (Gschwandtner 2019, p. 45). Each day on the Orthodox liturgical calendar is peppered with commemorations of saints and historical events. Through commemoration, the past is meaningfully taken up into the temporal horizon of anamnetic remembrance and eschatological hope. The presence of the past in the liturgical present is felt especially strongly on major feasts such as the Nativity of Christ on December 25. One of the main Orthodox Christian hymns for the feast reads, "Today the Virgin gives birth to the Transcendent One,/and the earth offers a cave to the Unapproachable One!/Angels with shepherds glorify Him!/The wise men journey with a star!/Since for our sake the Eternal God was born as a Little Child!"28 This hymn illustrates how, in liturgical temporality, the kairotic "today" straddles time and eternity, past and future. Gschwandtner writes, "Each moment matters profoundly, not as one in sequences of nows, but as the moment that encapsulates all of time. The heightened moment of the feast, then, in some way infects all of time, bleeds into the ordinary, and gives it significance." ${ }^{29}$ Liturgy's temporal horizon of remembrance and hope is not limited to salvific events in the distant past but provides a context for remembering more recent events as well. This is critically important in the $24 / 7$ age of systematic forgetting. Upon exiting the exhibition dedicated to the memory of the Holocaust at Yad Vashem, the Holocaust memorial center in New York, one reads, "Forgetfulness leads to exile, while remembrance is the secret of redemption." (Quoted in (Spiegel 2002, p. 156)). Forgetting has dire consequences, and a regular practice of remembrance must be cultivated to resist it. Liturgical temporality provides the context for such a practice.

Second, while 24/7 temporality militates against shared narratives in favor of fragmented, individual stories, liturgical temporality invites worshippers into a shared yet variegated story not of their own making. In liturgical time, "We are no longer the ones who open the world, but become dispossessed, swallowed up in the larger story." ${ }^{30}$ Liturgical time is meaningful precisely because "we" did not invent it; it did not begin with us (Gschwandtner 2019, pp. 54-55). This temporal structure could allow for communities to cultivate solidarity by seeing themselves, others, and the earth as players in an ongoing story of salvation and liberation in Christ, looking forward to renewed heavens and a renewed earth. As Pope Francis writes, "Solidarity, understood in its most profound meaning, is a way of making history." (Francis 2020, para. 116). The Orthodox Christian liturgical year contains overlapping stories, cycling through moments in the lives of Christ, the Virgin Mary, and others. These dense narrative layers allow individuals to seek out healthy differentiation within the broader, shared story and identify with persons or events that relate to circumstances within one's own personal life and life together. The time of year that is shared most fully by all is Holy Week, the week preceding Pascha (Easter). Every year, this week is packed with worship services commemorating the final days before Jesus's death and resurrection. Such a schedule, Gschwandtner notes, "wreaks havoc on one's 'normal' schedule - one enters into a different kind of temporality where regular time seems suspended." (Gschwandtner 2019, p. 46). Many parishioners take time off from work to attend lengthy services. This time spent deep within the shared story of redemption 
is felt to matter more than other times because of the worshippers' anticipation of the Paschal feast. This feast involves both spiritual and material preparation-prayer, fasting, cooking, and cleaning - and is colored by memories of past feasting. ${ }^{31}$ These communal practices can allow a spirit of solidarity and mutual aid to take shape as relationships grow and deepen. As people are guided by its rhythms of feasting and fasting, work and rest, liturgical temporality can gradually become the fabric of everyday life and lay claim to all time-season after season, year after year (Gschwandtner 2019, p. 49).

Finally, liturgical temporality thrives on meaningful repetition, which provides a context for the cultivation of habits of solidarity. As discussed above in Section 2 of this essay, the constant repetition of "new" yet functionally interchangeable digitally mediated experiences in 24/7 temporality was designed primarily for the extraction of maximum monetary value from time. The repetition at the heart of disaster capitalism, in the words of philosopher Maurice Blanchot, is "neither mournful nor nostalgic, the undesired return." (Blanchot 1986, p. 42). Rather than an endless repetition of novelty, the liturgy's repeated cycles of feasts, fasts, and commemorations allow communities to craft and appropriate a shared narrative arc of salvation, liberation, and human and non-human flourishing. Such an appropriation of a shared temporal horizon is not easy, nor is it guaranteed. Orthodox Christians sometimes complain of the repetitiveness and length of the services. Nonetheless, as Gschwandtner reminds the reader, one is shaped only by that which she puts her mind and body into. While ritual repetition can serve to perpetuate and enforce oppressive power structures, it can also allow for the formation of habits of solidarity when combined with educational, ethical, and other kinds of formation. ${ }^{32}$ These habits could have a concrete, transformative effect on a community and its surroundings. One could determine the success or failure of a community's efforts to embrace liturgical temporality as a time for solidarity by examining certain changes over long periods of time. Such changes could include an increase in the level of the community's engagement in local neighborhoods and habitats, the integration of religious education - oriented around cycles of liturgical time - and community action toward solidarity, and changes in perceptions of the community by those around it. In other words, embracing such a vision and praxis of liturgical temporality could allow inward practices of devotion structured by liturgical time to extend outward, to concrete actions that foster solidarity and liberation from the destructive effects of late capitalist $24 / 7$ temporality.

\section{Conclusions}

I have proposed that Christian traditions of liturgical temporality could provide a context for religious communities to cultivate solidarity between people of various classes, groups, and identities, and between human beings and the earth in resistance to the disaster capitalist regime of 24/7 temporality accelerated during the COVID-19 pandemic. Such solidarity within liturgical temporality is not a narrowly political form of resistance. To quote Blanchot, it is "spiritual resistance," a form of resistance without which political resistance is incomplete. He writes, "Resistance has no meaning, if not simply for oneself, or for the sake of friendship, which is rare. Only the religious have firm conviction capable of giving significance to life, and to death. Thus resistance is spiritual. Not until the revolts issuing from the depths ... do perspectives open — do ruined words become audible rising from the ruins, traversing the silence." ${ }^{33}$ Incorporating yet expanding upon practices of the Sabbath, shared liturgical temporality should embrace the creative tension between rest and action, preparation and celebration, remembrance and hope, at the varied timescales of weeks, seasons, years, and lifetimes. Such a multifaceted and yet unified temporality, to quote Castillo, "undercuts the ideological homogenization of time and, instead, foregrounds the community's hope in the power of God to redeem history." (Castillo 2019, p. 207). While ultimate redemption and liberation remain just beyond the eschatological border of liturgical time, they are nevertheless already present, breaking in with each act of love, justice, and forgiveness. 
Funding: This research received no external funding.

Conflicts of Interest: The author declares no conflict of interest.

\section{Notes}

$1 \quad$ See, e.g., (Bryson 2007; Derickson 2014; Veal 2019).

2 My understanding of the multivalency of solidarity in this paper is informed by Sobrino and Pico (1985). The authors write that solidarity is "another name for the kind of love that moves feet, hands, hearts, material goods, assistance, and sacrifice toward the pain, danger, misfortune, disaster, repression or death of other persons or a whole people ... The aim is to share with them and help them rise up, become free, claim justice, rebuild." (ibid., p. vii).

"Blursday" is not a neologism new to 2020; previously, it referred to a day spent hung over after a night of heavy drinking. See Alyeskyeyeva et al. (2020, p. 207). Craig D. Parks highlights the important role of social isolation due to virus prevention protocols in creating this disorienting sense of time. See Parks (2020, esp. p. 116).

4 Mathew Arthur aptly describes the digitally-mediated Blursday of the pandemic: "Time feels weird. The last two weeks have been a strange ten years. \#blursday is pandemic coming into form as a feeling of time trending on Twitter. It stretches out the present with scope-creeping domesticities, hangovers, professionalisms, streaming video, and oversleep. Days collapse into a dark-mode user interface, online shopping cart grid, anxious infographic, or COVID-19 meme." (Arthur 2019-2020, p. x).

5 See, e.g., (Kohan 2021; 2020).

6 See Fottrell (2021). I do not wish to suggest that the effects of this trend are solely negative. One can see working from home as an opportunity, for example, to spend more time with family and friends, eating meals, etc., and less time commuting.

7 (Klein 2007). See also Lowrey (2020).

8 See Sagan (2019). Crary writes, "24/7 is inseparable from environmental catastrophe in its declaration of permanent expenditure, of endless wastefulness for its sustenance, in its terminal disruption of the cycles and seasons on which ecological integrity depends." (Crary 2013, p. 10).

9 (Crary 2013, p. 9). See also the classic article by Thompson (1967).

10 (Le Goff 1960); translation in ibid., Time, Work, and Culture in the Middle Ages (Chicago: University of Chicago Press, 1980), pp. 29-42

11 Crary writes, "The homogenizing force of capitalism is incompatible with any inherent structure of differentiation: sacred-profane, carnival-workday, nature-culture, machine-organism, and so on." (Crary 2013, p. 13).

12 (Crary 2013, p. 29). Crary further remarks that the late-capitalist goal is to transform "all users into interchangeable objects of the same mass dispossession of time and praxis." (ibid., p. 58). Sagan issues a useful critique of Crary's singular focus on the present by stressing the peculiar futurity of late-capitalist temporality, writing, "But another facet of the very same temporalities consists of speeds and constant subjection of the everyday to a never sated, futurist state of desire for more (more information, more technological and newer, soon-to-become-obsolete devices, etc.)." (Sagan 2019, p. 158).

13 (Chan 2020, p. 6). Emphasis added.

14 (Crary 2013, p. 57). Emphasis added.

15 Philosopher Maurice Blanchot, writing about disaster time, notes that the fragmentation of time amidst disaster does not allow for fixity, but rather "disarray [and] confusion." (Blanchot 1986, p. 7).

16 See, e.g., Odell (2019). The website The Nap Ministry advertises sleep as liberation and a means of clogging the gears of capitalist production and consumption. See https: / thenapministry.wordpress.com/ (accessed on 7 May 2021). Both of these sources find inspiration in performance art for imagining alternative temporalities to 24/7 temporality. For Heschel's partnership with Martin Luther King Jr. in organizing and activism, see Heschel (2018).

18 (Dawn 1989). For a critique of the notion of Sunday as Christian Sabbath, see Searle (1995).

19 Norman Wirzba recognizes, "It is important to realize that we will not be able to do this easily as individuals. Sabbath practices are corporate in nature, which means that we will need to enlist the help of others to keep us accountable and true to out better intentions." (Wirzba 2006, p. 151). However, he offers no communal strategies for the cultivation of Sabbath practice in a Christian context.

20 While many do discuss Sunday as a Christian Sabbath, they often criticize Puritan-inspired practices like work prohibition on Sundays, instead advocating practices of rest a regular day of the week that would, hopefully, influence the way in which one uses time throughout the rest of the week. See, e.g., Wirzba (2006, p. 91).

21 Consumerism is not co-terminus with capitalism, though they are obviously linked. It is important to note the extent to which the pursuit of desires, usually in the form of consumer goods, is intimately linked with corporate interests 
of maximum profitability in late capitalism. Theologian Kathryn Tanner puts it this way: "Whether at home, at the store, or at work, one should be the sort of person who assumes responsibility for making the most of what one has in pursuit of one's goals: the ever greater achievement of self-realization and self-fulfillment. Put into more financialized terms ... one should make every effort, in a self-directed way, to maximize the profitable employment of assets one has in one's person." (Tanner 2019, p. 73).

Such actions could include participating in local projects for fair housing and equitable access to healthy food and water, advocacy on behalf of residential areas disproportionately affected by pollution, protests, phone banking, and sit-ins for racial and environmental justice, and so on.

23 (Winner 2018). Winner critiques a prevalent, if mostly unspoken, assumption in postliberal theologies of practice that Christian practices always do what they are supposedly intended to do: form moral communities oriented towards virtue and sanctity. See (ibid., pp. 167-80).

24 Ritual theorist Catherine Bell notes, "Calendrical distinctions are effective in solidifying group identity, while the appropriation of local rites acts to extend that identity to new subgroupings." (Bell 1997, p. 105).

25 Such exclusivism around liturgical time can be understood, at least in part, as an effort to hold onto a sense of group identity in the midst of a changing world. See Demacopoulos (2017, esp. pp. 484-89).

26 (Gschwandtner 2019). Within the scholarly literature on ritual, time is a surprisingly neglected theme. One important exception is Roy Rappaport (1992). I have chosen to engage Gschwandtner as a primary conversation partner in this section because she is especially attentive to Christian ritual time in light of the Christianity's particular spiritual and ethical claims.

27 Gschwandtner describes liturgical temporality thus: "Instead of a linear experience that moves from past through the present to the future, time is experienced as the horizon within which we experience our liturgical being; it is the 'how' of our 'being' in its world." (Gschwandtner 2019, p. 44).

28 The Kontakion hymn for the Feast of Nativity on December 25 by the sixth-century hymn writer Romanos the Melodist. Translation from Orthodox Church in America, https:/ / www.oca.org/saints/troparia/1000/12/25/10363 8-the-nativity-of-our-lord-god-and-savior-jesus-christ (accessed on 8 March 2021). For a perceptive discussion of time and communal identity in the hymns of Romanos, see Krueger (2014, pp. 66-105).

29 (Gschwandtner 2019, p. 55). It is important to mention that the Christian liturgical year developed in ancient and medieval temporal milieux foreign to modern notions of time as linear and quantifiable. One moves back and forth between past, present and future such that the modern worshipper might feel they are "time-travelling." But the point is that the present is subject to past and future, and is indeed structured by them. See the discussion in (ibid., pp. 43-45).

30 (Gschwandtner 2019, p. 46). She continues, "Our present reality is at the very least affected, possibly challenged and transformed by the liturgical reality that becomes present in our celebration of it." (ibid., p. 46).

31 (Gschwandtner 2019, p. 47). She continues, "We 'give up' other time-sometimes even quite inordinate amounts of time-in order to 'have the time' for celebration." (ibid., p. 48).

32 (Gschwandtner 2019, pp. 51-52). Ritual theorist Ronald Grimes wisely notes, "Rites may become not only irrelevant but oppressive. In the wrong hands, they can be tools for oppression as surely as they can be instruments of healing." See Grimes (2002, p. 293).

33 (Blanchot 1986, p. 83). See also Castillo (2019, p. 208).

\section{References}

Alyeskyeyeva, Iryna O., Tetyana A. Chaius, and Elizaveta A. Galitska. 2020. Coronaspeak as Key to Coronaculture: Studying New Cultural Practices Through Neologisms. International Journal of English Linguistics 10: 202-12.

Anonymous. 2020. Big Tech Companies, Fully Recovered from Pandemic, Report Record Earnings. CBS News. October 29. Available online: https:/ / www.cbsnews.com/news/google-apple-amazon-facebook-twitter-big-tech-record-earnings-q3-2020/ (accessed on 7 March 2021).

Arthur, Mathew. 2019-2020. Writing Pandemic Feels. Capacious: Journal for Emerging Affect Inquiry 2: vi-xxiii.

Bell, Catherine. 1997. Ritual: Perspectives and Dimensions. Oxford: Oxford University Press.

Bell, Genevieve. 2021. Pandemic Passages: An Anthropological Account of Life and Liminality during COVID-19. Anthropology in Action 28: 79-84. [CrossRef]

Blanchot, Maurice. 1986. The Writing of the Disaster. Translated by Ann Smock. Lincoln, London: University of Nebraska Press.

Brueggemann, Walter. 2017. Sabbath as Resistance: Saying No to the Culture of Now, rev. ed. Louisville: Westminster John Knox Press. Bryson, Valerie. 2007. Gender and the Politics of Time: Feminist Theory and Contemporary Debates. Bristol: Policy.

Castillo, Daniel P. 2019. An Ecological Theology of Liberation: Salvation and Political Ecology. Maryknoll: Orbis.

Chan, Nadine. 2020. Pandemic Temporalities: Distal Futurity in the Digital Capitalocene. Journal of Environmental Media 1: 1-8. [CrossRef] 
Crary, Jonathan. 2013. 24/7: Late Capitalism and the Ends of Sleep. London: Verso.

Dawn, Marva J. 1989. Keeping the Sabbath Wholly: Ceasing, Resting, Embracing, Feasting. Grand Rapids: Eerdmans.

Demacopoulos, George. 2017. 'Traditional Orthodoxy' as a Postcolonial Movement. Journal of Religion 97: 475-99. [CrossRef]

Derickson, Alan. 2014. Dangerously Sleepy: Overworked Americans and the Cult of Manly Wakefulness. Philadelphia: University of Pennsylvania Press.

Fottrell, Quentin. 2021. Will COVID-19 Push More Employees to Work Remotely after the Pandemic? This Economist Says Yes. Marketwatch. December 27. Available online: https:/ / www.marketwatch.com/story/does-covid-19-have-the-power-to-revolutionizework-this-economist-says-yes-2020-12-11 (accessed on 7 March 2021).

Francis. 2013. The Joy of the Gospel: Apostolic Exhortation, Evangelii Gaudium, of the Holy Father Francis to the Bishops, Clergy, Consecrated Persons and the Lay Faithful on the Proclamation of the Gospel in Today's World. Available online: http:/ / www.vatican.va / content/francesco/en/apost_exhortations/documents/papa-francesco_esortazione-ap_20131124_evangelii-gaudium.html (accessed on 7 March 2021).

Francis. 2020. All Brothers: Encyclical Letter, Fratelli Tutti, of the Holy Father Francis on Fraternity and Social Friendship. Available online: http:/ /www.vatican.va/content/francesco/en/encyclicals/documents/papa-francesco_20201003_enciclica-fratellitutti.html (accessed on 20 April 2021).

Grimes, Ronald L. 2002. Deeply into the Bone: Re-Inventing Rites of Passage. Berkeley: University of California Press.

Gschwandtner, Christina M. 2019. Welcoming Finitude: Toward a Phenomenology of Orthodox Liturgy. New York: Fordham University Press.

Hartman, Laura M. 2011. Christian Sabbath-keeping as a Spiritual and Environmental Practice. Worldviews 15: 47-64. [CrossRef]

Heschel, Abraham Joshua. 1951. The Sabbath: Its Meaning for Modern Man. New York: Farrar, Straus, and Young.

Heschel, Susannah. 2018. A Friendship in the Prophetic Tradition: Abraham Joshua Heschel and Martin Luther King Jr. Telos 182: 67-84. [CrossRef]

John Paul II. 1998. The Lord's Day: Apostolic Letter, Dies Domini, of the Holy Father John Paul II to the Bishops, Clergy and Faithful of the Catholic Church on Keeping the Lord's Day Holy. Available online: http://www.vatican.va/content/john-paul-ii/en/apost_ letters/1998/documents/hf_jp-ii_apl_05071998_dies-domini.html (accessed on 7 March 2021).

Klein, Naomi. 2007. The Shock Doctrine: The Rise of Disaster Capitalism. New York: Picador.

Kohan, Shelley E. 2021. Amazon's Net Profit Soars 84\% With Sales Hitting \$386 Billion. Forbes. February 2. Available online: https: //www.forbes.com/sites/shelleykohan/2021/02/02/amazons-net-profit-soars-84-with-sales-hitting-386-billion/ (accessed on 7 March 2021).

Krueger, Derek. 2014. Liturgical Subjects: Christian Ritual, Biblical Narrative, and the Formation of the Self in Byzantium. Philadelphia: University of Pennsylvania Press.

Le Goff, Jacques. 1960. Au Moyen Age: Temps de l’Eglise et temps du marchand. Annales: Histoire, Sciences Sociales 15: 417-33. [CrossRef]

Lowrey, Annie. 2020. Don't Blame Econ 101 for the Plight of Essential Workers. The Atlantic. May 13. Available online: https://www. theatlantic.com/ideas/archive/2020/05/why-are-americas-most-essential-workers-so-poorlytreated/611575/ (accessed on 7 March 2021).

Odell, Jenny. 2019. How to do Nothing: Resisting the Attention Economy. New York: Melville House.

Parks, Craig D. 2020. Group Dynamics When Battling a Pandemic. Group Dynamics: Theory, Research, and Practice 24: 115-21. [CrossRef]

Rappaport, Roy. 1992. Ritual, Time, and Eternity. Zygon 27: 5-30. [CrossRef]

Sagan, Claire. 2019. Capitalist Temporalities as Uchronia. Theory \& Event 22: 143-74.

Searle, Mark. 1995. Sunday: The Heart of the Liturgical Year. In Between Memory and Hope: Readings on the Liturgical Year. Edited by Maxwell E. Johnson. Collegeville: Liturgical Press, pp. 59-76.

Sobrino, Jon, and Juan Hernández Pico. 1985. Theology of Christian Solidarity. Maryknoll: Orbis.

Spiegel, Gabrielle M. 2002. Memory and History: Liturgical Time and Historical Time. History and Theory 41: 149-62. [CrossRef]

Tanner, Kathryn. 2019. Christianity and the New Spirit of Capitalism. New Haven: Yale University Press.

Thompson, Edward P. 1967. Time, Work-Discipline, and Industrial Capitalism. Past E Present 38: 56-97.

Veal, Anthony James. 2019. Whatever Happened to the Leisure Society? Abingdon: Routledge.

Winner, Lauren F. 2018. The Dangers of Christian Practice: On Wayward Gifts, Characteristic Damage, and Sin. New Haven: Yale University Press.

Wirzba, Norman. 2006. Living the Sabbath: Discovering the Rhythms of Rest and Delight. Grand Rapids: Brazos Press. 